\title{
The Clearing
}

\section{Heidegger's Lichtung and the Big Scrub}

\section{ROB GARBUTT}

In the midst of beings as a whole an open place occurs. There is a clearing, a lighting.

This essay is concerned with the situatedness of being local, of being a local, and of being one of the locals. And with just one aspect of that: the clearing.

There is a clearing into which we locals are born, from which we are born, and which we maintain and alter: autochthons within this place, children of this clearing that we inherit and share, running its slope jumping foxtail tussocks, pause-hearing-feeling the breeze say rain, smelling Christmas beetles emerging at dusk-November, my sister remembered driving past her grave.

From the Heights Bowlo balcony on Friday afternoon, safe at our backs, we sip and survey this clearing north to the hills behind Nimbin, 
encompassing, enclosing, cosy.

No worries. No worries.

This essay is concerned with the situatedness of being local, of being a local, and of being one of the locals. It is particularly concerned with the clearing in which the locals are able to make their appearance with 'no worries', and the relationships between the locals and local Indigenous Australians that constitute key elements of that clearing.

-II

This essay is one part of a larger project on locals that began as a project of reconnecting to my place of birth, childhood and adolescence: Lismore, on the farnorth coast of New South Wales. ${ }^{2}$ In 1999 I returned to live in this place, after twenty years spent in Sydney, and I longed to recline in the comfort of seeing those distant Nimbin hills, to walk barefoot on this ground again. Within that context I began to think about a question: 'What', I wondered, 'does it mean to "be a local" in Lismore?'

For much of my life, being a local, and the word local, were not objects of thought that had occupied me; one is a local. Such things are claimed and naturalised as part of one's being. So the very idea of making 'being a local' into a question and then going to the trouble of making it a research project signals a shift in experience. Michel Foucault argues that an object of thought is constituted when something has 'happened to introduce uncertainty, a loss of familiarity'. Furthermore, 'that loss is the result of difficulties in our previous way of understanding, acting, relating'. ${ }^{3}$ On reflection, returning to Lismore was no pure return to being a local, no straightforward repetition, no beginning again either for Lismore or for me. This confluence was 'proceeding from the middle, through the middle'.

Once alert to the idea, I saw that we locals are constantly in the news. In the local print media the locals are continually asserting a privileged connection to place in their encounters with others. At nearby Byron Bay, a popular stop on global backpacker routes, the locals, tourists and tourism interests constantly jostle over 'ownership' of public space. This particular example has a regional historical context. Since the 1950s, the sub-tropical coastal rurality of the region has drawn a 
significant and steady sea- and tree-change migration, which accelerated from the 1970s onwards. ${ }^{5}$ For the country-minded Lismore of the 1970s it was the Aquarius Festival at nearby Nimbin, an alternative student happening held over ten days in 1973 which never really ended, that gave the locals greater cultural visibility. Thirty years later the 'hippie' or 'new settler'-local divide has blurred considerably, though often reinscribed in situations of cross-cultural tension. In these and a range of other contexts questions of who properly belongs here, who may assert cultural possession of public space, and who may or may not speak for a place, are often settled in terms of who is or is not a local and, failing that, who is the more local. While my interest (and local identity) is located in Lismore, making place important to identity is not just a local or a rural thing; the locals also make metropolitan appearances, sometimes with national-scale inflections. For example, when the locals of Sutherland Shire (locally known as 'The Shire') asserted their right to enforce local ways of belonging during the Cronulla riot of 2005, this was more than an issue of local beach etiquette: it was an assertion of national possession as well. ${ }^{6}$

This sense of possessive localism is one I understand and often inhabit. Despite my twenty year absence from Lismore I still regard myself as 'a local'. Generations of births and deaths in the Lismore area provide me with a landscape layered with family stories, while my own childhood and teenage years in Lismore intertwine places, history, home, identity and personal experience into a coherent and chaotic whole. It is this family history and personal experience on which I base my claim to being a local in this place.

Through embodied experience I came to think of certain places in and around Lismore as having particular significance for me, and over which I felt a 'special' sort of ownership. Being a local can be very specific. Special among my places are a hillside and a creek where I learnt to appreciate what I then experienced as my 'natural environment', and which I subsequently recognise as an environment transformed through colonial agricultural practices: in that sense, a natural environment indeed. It was here that my friend Dave and I spotted our first tawny frogmouths. We understood the slope of this hill in our bodies, through the threeway relationship between running 'full pelt' down it, 'flying' over grass tussocks, and staying upright. Lower down the hill we would stop beneath a towering forest relic we called the Kestrel Tree and stoop to pick up the regurgitated kestrel pellets in an 
attempt to discover the diet of those beautiful birds of prey nesting high above us. It was on this hillside that we would, towards the end of our primary school days, smash the concrete survey markers, and pull up the surveyors' pegs in our naive eleven-year olds' attempt to stop the transformation of our sanctuary into Southern Cross University. And it is here that I began working on this project about being a local. But, as I said, after twenty years living away from 'home', being a local in these ways could not be repeated.

Perhaps thinking could settle what had become a problem for study.

Then more trouble appeared on the horizon.

-III

In the year 2000 my partner and I went to the annual Fairymount Festival at Kyogle, a town about thirty minutes northwest of Lismore. At this time the debate around the issue of reconciliation between Indigenous and non-Indigenous Australians was at its zenith. Part of the festival was an exhibition of reconciliation art in the Roxy Gallery, and as part of this exhibition a Sorry Book was placed in one corner. This was a message book, a place for people to respond to the 'sorry business' detailed in the Bringing Them Home report and, I suspect, a more general site for affirming support for reconciliation in general. ${ }^{7}$ Certainly for me the two issues were conflated.

Though I agreed with reconciliation I was not committed to signing the sorry book. There was an inconvenient line of about six people waiting their turn to sign and if it had not been for my partner's intention I would have followed the aroma of a sausage sizzle to the street outside. Nonetheless, somewhat shamed through conformity into patience, I waited my turn. The line in front of me shortened and, peering over the shoulders of others in front, I noticed that this would not just be a simple exercise of signing. In the book there was a 'message' column in which people were expressing something of their feelings. I felt rising panic at the reality of committing myself to some form of substantive verbal expression in the sorry book. What began as conformity became a question of sincerity. What in all honesty could I say of my sorrow when it was more accurate to describe my feelings as a mixture of fear, guilt and confusion: fear of Aborigines even though (or because?) I didn't have any sustained interaction with Aborigines to base that fear on; a degree of guilt 
at what had happened in the past although I felt distant from it; and confusion about how I fitted into a process of reconciliation to which I had only paid lip-service.

Reconciliation was suddenly becoming personal and this was not a feel-good moment. The Sorry Book demanded a conscious response to Indigenous oppression and white privilege. As a representation of Indigenous Australians, the book brought me face to face with my imagined Other, an Aboriginal mother of a Stolen Generation child. As I approached this vision the question on her lips was straightforward.

'What do you want to say to me?'

I was at a point in a line at a time when the denial of the Aboriginal presence seemed less possible. The Sorry Book was an intervention that demanded my attention and confounded my senses.

In the narrow column headed 'message' I wrote, 'I don't know what to do'.

My clumsy message preceded a strong bodily reaction. I walked from the Roxy Gallery with legs no longer solidly in contact with my known earth. It was as if I was on shaky ground. The ground of my birth and the personal sites of significance that had warmed me with nostalgic familiarity felt somehow corrupted and no longer 'mine'. These places had belonged to Bundjalung people, were stolen and not returned. ${ }^{8} \mathrm{I}$, in turn, had claimed them as my own. I come from here. I'm a local. This is my place, but now my here was a troubled possession. There was no going home. In the terms used by Gooder and Jacobs, I had entered the realm of the 'guiltafflicted', 'dispossessed settler', suffering from a Nietzschean 'bad conscience' and a severe melancholy of loss. ${ }^{9}$

In the months that followed, my initial interest in thinking through how one might reconnect to a sense of being a local in Lismore took a new shape. Within this local identity I was beginning to recognise that someone had been concealed, dissembled. By dissembling, Martin Heidegger proposes that '[o]ne being places itself in front of another being, the one helps to hide the other, the former obscures the latter, a few obstruct many, one denies all. ${ }^{10}$ The sorry book was a 'space clearing gesture' that, to me, unconcealed the Aborigines dissembled by the locals. ${ }^{11}$ In my mind it brought Bundjalung people out from behind a single category that denies others' claims of belonging.

While my memory of childhood was of an upbringing that encouraged empathy and compassion, how was it, I wondered, that I had learnt and embodied 
this concealment and denial? How did I unproblematically come to consider myself to be a local? With what concepts and practices have Australian settlers installed themselves as 'local' or 'original'?

-IV

Developing an understanding of concepts that inform settler practices of 'installation' as locals requires a local analysis. In 'Walking in the City' Michel de Certeau surveys New York from his vantage point in the theory-laden heights of the 110th floor of New York's now destroyed World Trade Center: 'looking down like a god', the 1370-foot high tower makes the 'complexity of the city readable' but only, he says, as a work of fiction. The theoretical panorama of the city is based on vision, 'the solar Eye', the 'lust to be a viewpoint and nothing more', that misunderstands the practices of the walkers who 'make use of spaces that cannot be seen'. ${ }^{12}$ To develop some understanding of the world of practices one must first 'descend' from theoretical heights and walk, criss-crossing the city with paths that begin to give shape to the topography of interest. ${ }^{13}$ These paths, or narratives, become 'a field of operations within which theory is itself produced.. ${ }^{14}$ In this case, theory, in its particularity, cannot explain all.

Unlike de Certeau's metaphorical descent to the streets visible from the World Trade Center, in my analysis of local practices I want to return to the site of Lismore on the coastal plain in eastern Australia. What theory of local practices can be produced here? One hundred and sixty years ago and momentarily suspended 1370 -feet in mid-air we would descend to crash through the canopy of a rainforest to the dark, dank forest floor below. In the 1850s Mary Bundock wrote of this 'semitropical jungle', 'I have walked through it for miles and never seen the sun ... As you stood and looked around your view was bounded by the great brown tree stems which closed in around me'. ${ }^{15}$ There is no obvious path through this shadowy world; however, a patch of light draws our attention. We make our way across a composting floor of leaf litter towards a lighted clearing, clambering over logs and stopping frequently to unhook the claw-like barbs of the wait-a-while vine from our clothes. $^{16}$

Mary Bundock's 'jungle' became known to (mostly English, Scottish and Irish) settlers as the Big Scrub, a myopic tangle rich in timber. It was the value of this 
timber, especially the large quantities of red cedar, which, with the aid of Aboriginal guides, first drew colonists to it in the spring of October $1842 .{ }^{17}$ The Big Scrub was located on a volcanic-soil plateau in the north-east corner of New South Wales covering 700 square kilometres. ${ }^{18}$ Tributaries of the Wilson River flowed through the Scrub, and it is at the junction of two of those tributaries, Wilson and Leycester creeks, that the town of Lismore was first surveyed as a site for a village in $1855 .{ }^{19}$ Clearings, such as the one that draws our attention in the darkness, occurred naturally within the Scrub, and in the settler tongue these were named with the suffix 'grass'; hence just outside Lismore there is Chilcotts Grass, Howards Grass and Lagoon Grass. For the cedar cutters these grasses provided relief from the claustrophobic rainforest, but more importantly provided relief from the labour of clearing which was needed for erecting shelters in the forest. ${ }^{20}$

Perhaps more significantly for these colonists, the grasses provided pasture for the bullock teams that pulled sawn logs through the rainforests to creek banks for the downstream leg of the journey to mills and the Sydney and London markets. Once within these clearings, bullocks could be left to roam, as they would not wander into the vast expanses of forest where there was insufficient fodder. ${ }^{21}$ Many of the earliest named grasses were named after timber getters or owners of bullock teams: Chilcotts Grass, Dan's Grass, Oestrich's Grass and Webster's Grass. ${ }^{22}$ These clearings were productive spaces in the form of enclosures that enabled economic survival for the early colonists. They may have also been early sites of sustained contact with Bundjalung people in the Lismore area. While the grasses appear to be natural in origin, many of these clearings were used by Aborigines as ceremony grounds, and were kept clear for that purpose. ${ }^{23}$

In the 1840 s and 1850 s grazing of livestock in the Lismore district took place on 'runs', extensive leasehold properties on open forested country to the west of the rainforest that required little large-scale clearing. Likewise, timber getters working the Big Scrub did little large scale clearing. They worked by picking out high value trees one by one. This situation changed when crown land was made available to selectors as freehold property with the passing of the Robertson Land Acts of 1861. In 1862 clearing made a significant transition from noun, to verb, and back to reworked noun. Selectors started to take up selections in the Big Scrub for intensive agriculture. It was now that the grasses provided significant sites from which to 
stage a project with determined civilising intent: the clearing of the Big Scrub for 'improvement' and cultivation. The significance of the grasses to selectors as available pasture within the thick rainforest was such that in 1880 it was proposed that a series of them should be reserved as public commons. ${ }^{24}$ Clearing of the Big Scrub was so rapid, however, that the reserves were never gazetted. A race was on. Selectors depended on creating pasture and cropland in order to pay off and satisfy the requirements of their three-year government loans. To this end, government surveyors made regular journeys to determine the extent of selectors' clearings and buildings, the 'improvements', and from these determine if an additional loan repayment was required. ${ }^{25}$ Clearing was a personal financial imperative, an element of new land ownership laws, and an instrument of the ideology of 'improvement'.26

Today the clearing of the underbrush, vines, dead wood and timber of the Big Scrub has become the stuff of local history and pioneering legend. The clearing of the Bundjalung people from that same land is the stuff of silence. In an ecological lament Harry Frith states that 'until 1842 no white man had penetrated [the Big Scrub] and, until 1862 no farmer had dug in its soil. But by 1900 the forest was gone and its ashes, washed into the deep red soil had left not even a black stain on the surface. ${ }^{, 27}$ Not a stain left-another sense of the 'Big Scrub'. We could reinterpret Frith's last sentence as a statement of Aboriginal and settler contact history, though such an interpretation overstates colonial effectiveness and ignores Aboriginal resilience and resistance. While settlers may often behave as though the colonial project of clearing had been taken through to completion, this was never achieved. Aborigines have always been present, yet in the colonial imagination settlers steadfastly resist seeing the cleared area of the Big Scrub as a shared landscape. Here the clearing takes the form of a place of concealment.

An analysis of the contemporary use of the word 'local' reveals how, in this cultural practice, the idea of being 'a local' stabilises local settler belonging through the concealment of self and others. A local, understood as 'an inhabitant of a particular locality' is a substantive, the noun-equivalent, of the adjective 'local'.28 In the substantive, therefore, the noun which the adjective 'local' modifies is understood, elided, concealed. This opens the question, what is the concealed noun? As is often the case, it is somewhat simpler to determine what the concealed noun is not. 
A critical language study of seventeen months of the regional daily newspaper, Northern Star, shows that within everyday settler discourse Aborigines are never substantive-locals. ${ }^{29}$ This, it seems, would disrupt the clearing, the place of 'the locals', with others. Instead, Aborigines are adjective-locals. In the Northern Star Digby Moran is described as a 'local ... indigenous artist'.30 Bill Walker, the coordinator of the Bundjalung Nation Aboriginal Cultural Heritage Committee, is a 'respected local identity'. ${ }^{31}$ These two instances are illustrative of the repeated use of the term 'local' as an adjective in reference to Aborigines. Local is a modifier of the nouns 'artist' and 'identity', indeed a modifier that refers to an imagined boundary rather than to the land itself. If there was a class of substantives to which 'local' belonged, we would be justified in labelling them dispossessives.

The clearing, then, occurs as more than an open field where the Big Scrub once stood. It is a 'space clearing gesture' which allows new ideas and connections to develop. ${ }^{32}$ In this locale it also connects with past and present physical and psychical practices of identity formation through labour, place-making and dwelling. My sense of being local emerges from colonial practices of clearing land that made it available for agriculture and that created a familiar landscape when compared with received images of English rurality; and this sense of being local is made unproblematic by clearing the settler-mind of Indigenous others in preparation for self-installation as a local within that space. The language of being a local is itself part of the activity that is enabled and constrained by this clearing. ${ }^{33}$

The idea of 'the clearing' makes its appearance as already troubled, yet compelling because of its contested and locally layered meaning. As I have already sketched out, clearing as a verb provides individual connections with local historical narratives. These local historical narratives of clearing and cultivation connect to weave national stories. Since the 1800 s the colonists and, later, the citizens of Australia, have imagined the 'progress of civilisation' in forested areas to commence with clearing, and from south of Sydney to north of Brisbane the historical progression from cedar getting via clearing to intensive agriculture is a common storyline. Contemporary environmental and economic debates over the practice of clearing continue throughout Australia. To stop clearing is, many believe, to retard progress. $^{34}$ 
The work of clearing, with its local inflections and its individual intentions, results in a socially shared clearing, a stage on which local and national cultural productions make their appearance. Specifically, this clearing is an open place on which being a settler local depends and in which settler Australians find being a local is possible. Within this clearing, as a socially shared place, and as an enclosure that excludes and enables, the locals represent a powerful and self-proclaimed limit to belonging in a place.

$-\mathrm{V}$

Martin Heidegger develops the idea of Lichtung to explain the specific circumstances, the situatedness, of our being in the world. ${ }^{35}$ Lichtung, typically a lighted clearing occurring within a forest, here 'designates a bringing to light which is also a clearing of space'. ${ }^{36}$ In 'The Origin of the Work of Art' Heidegger introduces the term as follows: 'In the midst of beings as a whole an open place occurs. There is a clearing, a lighting [Lichtung]. ${ }^{, 37}$

Heidegger utilises Lichtung as a way of discussing those things and beings that are able to 'show up as something' in our collective midst, things that appear as true. $^{38}$ Here, Heidegger's concept of truth derives from his wordplay with the classical Greek word for truth, alethia, which he reads as unconcealment ( $a=$ un, lethe = conceal (also, forget)). Within the clearing, truths, as beings, are revealed or unconcealed, and within the clearing beings experience what they are, what they can be, and what they are not. ${ }^{39}$ As Heidegger puts it, 'only this clearing grants and guarantees passage to those beings that we ourselves are not, and access to the being that we ourselves are'. ${ }^{40}$ As 'this clearing'-it has its particularities-occurs in the 'midst of beings as a whole', it is also a cultural place that is continually being made and remade. As with the clearing of the Big Scrub, it is a place and a work, it has the qualities of a space and an event, of repetition and of change. What appears is 'never [on] a rigid stage with a permanently raised curtain'. ${ }^{41}$ Indeed, Heidegger distinguishes 'clearing as an activity from the clearing that results from that activity. Think of a group of people all working together to clear a field in a forest. There is a plurality of activities of clearing, but all this activity results in only one cleared field.'42 
The clearing is pre-representational: it is an affective situation that is the background to being. It governs what can appear; what is concealed by what appears; what appears as that which it is not. It is not at all clear, but it shapes. Contributing to the clearing is land; landscapes; the sounds of the clearing, birds, traffic; skin colour; axes, saws, ceremonies, governments, property lore; weather; distance, markets and empires; language, newspapers; inhabitants of many origins; their ways, all together. There is also power throughout this network. The power I have been interested in is in the activity of settler self-representation within a clearing where the lighted limit is Aboriginal peoples. The relationship of the locals to Indigenous people, in that direction, enters the darkness and connects to people who cannot be unconcealed as locals without disruption in return. This is a place that is defensively autochthonous as a consequence, in which locals are fearful of repossession, and stories of one's migration are repressed.

\section{$-\mathrm{VI}$}

The clearing, as I imagine and describe it, connects with a larger-scale clearing in which a literature of settler indigenisation appears, literature that is concerned with theorising memory, concealment and place in local, national and transnational contexts. Deborah Bird Rose, for example, writes of an experience in which a nonIndigenous guide takes tourists across a threshold in which 'the mantle of belonging to the land (autochthony)' has been imaged as passing from Aborigine to settler. ${ }^{43}$ Kate Grenville reflects on the motif of 'concealing and simultaneously revealing' that accompanied her as she researched her novel The Secret River; a motif that takes form in the language of settlers and the practice of imagining oneself 'going native' while camping in the bush.44 I have also explored the effects of an 'Australian language of settlement', while Ian McLean has analysed this settler imaginary in Australian art. ${ }^{45}$ Literary critic Terry Goldie provides one of the earliest analyses of indigenisation in settler nation-states in his analysis of representations of indigenes in Canadian, Australian and New Zealand literature. ${ }^{46}$ Goldie defines indigenisation as the process 'through which the "settler" population attempts to become as though indigenous, as though "born" of the land'. ${ }^{47}$ Accompanying this social production of indigenisation is a political production: the land 'as a natural nation'.48 Indigenisation is necessarily and simultaneously local and national: the 'impossible 
necessity' 'to become "native," to belong here'.49 David Pearson argues that indigenisation represents a move from a settler to a post-settler position which signifies detachment from the British motherland and identification as a "native" of a new land, a move from 'home there' to 'home here'.50 For Pal Ahluwalia, the 'myth of terra nullius was dependent upon the non-recognition of the local population and the "indigenisation" of their white conquerors', a process which began, he asserts, when 'white colonists were locally-born'.51

In evoking the clearing I am attempting to describe an affective place in which the expression of settler indigenisation is made possible, a place that enables memory and concealment. The particular clearing in this essay, the Big Scrub, in which settler locals like me make our appearance, is a material and pre-conceptual stage which limits complexity and connection. It designs a particular story, though in postcolonising times it doesn't contain as well as it used to. In the midst of the locals, the clearing allows the possibility of imagining terra nullius as truth, from which generations of locals may be born and bred and claim to have always been from here. Our stories are not of migration but of local births and deaths, of old families and histories which begin with first selections, pioneering and clearing the Scrub. Our clearing is autochthonic, where the locals are born of the soil with which they have mixed their blood, sweat and toil.52 This local identity is at once both local and national, the locals of this place and the native-born of this nation are coproductions within the limits this clearing affords.

'What, then, is it you want to say to me?'

Responses to this question, words that earlier I put into the mouth of an imagined Stolen Generations mother, echo through this essay. My initial response'I don't know what to do' - reminds me of a poem by Geoff Page who writes of the day a Sorry Book made the rounds of his school staff room:

...no more articulate,

their phrases likewise close to mawkish,

cliches in themselves declaring

words are not enough. 53

Words are not enough, but they are also one means of expression for settlers questioning how to 'live well in a colonised land'.54 The clearing, in this essay, is offered as one of those expressions. The clearing, following Heidegger, is an attempt 
to put into words that place which is prior to words and representation, a place of being and doing, that nevertheless governs the possibilities of what can be done and said. It is the place in the midst of a group of people, in this case the locals, that makes the questionable-that the locals are the colonisers and the Aborigines never locals-a possible and natural way of being. The clearing-that place which Heidegger would say we ourselves are ${ }^{55}$-brings to the edge of awareness that which is cleared away or is concealed so that ideas, practices and possibilities can appear. With this awareness, this local place is potentially transforming for the clearing in which we dwell, a place which can be no longer experienced as the same. One wanders in such a place, can't return home, can't walk in the same places even though it is the same land that is walked.56 Displaced maybe, uprooted maybe, not without worries, becoming allochthonous, not so native-born, not knowing what to do; and for all that open to new possibilities of being connected to and in this place; ways that are opening to others, their connections and belongings; and ways that acknowledge places and migrations in local settler identity. Clearing together, in our separateness, to create new social places.

Rob Garbutt teaches cultural studies at Southern Cross University, Lismore. Rob's interests include the connections between people, non-people and places, especially that connection called belonging. <rob.garbutt@scu.edu.au>

\footnotetext{
-NOTES

${ }^{1}$ Martin Heidegger, Poetry, Language, Thought, trans. A. Hofstadter, Harper \& Row, New York, 1971, p. 53.

2 This essay draws extensively on Rob Garbutt, The Locals: Identity, Place and Belonging in Australia and Beyond, Peter Lang, Oxford, 2010, chapter 1.

3 Paul Rabinow, Anthropos Today: Reflections on Modern Equipment, Princeton University Press, Princeton, 2003, p. 18 (quoting and translating Foucault).

4 Gilles Deleuze and Felix Guattari, A Thousand Plateaus: Capitalism and Schizophrenia, trans. B Massumi, Continuum, London, 1987, p. 25.

5 Johanna Kijas, 'Moving to the Coast: Internal Migration and Place Contestation in Northern New South Wales', PhD thesis, University of Technology, Sydney, 2002, p. 116.

6 See: Clifton Evers, 'Locals Only!', in Selvaraj Velayutham and Amanda Wise (eds), Proceedings of the Everyday Multiculturalism Conference, 2006,

$<$ http://www.crsi.mq.edu.au/news_and_events/documents/cliftonevers_000.pdf>; and Aileen
} 
Moreton-Robinson and Fiona Nicholl, 'We Shall Fight Them on the Beaches: Protesting Cultures of White Possession', Journal of Australian Studies, no. 89, 2007, pp. 149-60.

7 In 1997 the Human Rights and Equal Opportunities Commission, a federal statutory body, published its report from the two-year National Inquiry into the Separation of Torres Straight Islander Children from their Families as Bringing Them Home: National Inquiry into the Separation of Aboriginal and Torres Strait Islander Children from their Families, HREOC, Canberra, 1997. This report brought into public view the tragic effects on Indigenous communities of Australian governments' policies of removing children of mixed heritage from their families. The oral testimonies of children and parents in the report conveyed the sense of ongoing trauma experienced daily by many Indigenous Australians as a result of assimilation policies that were in effect from the early 1900s to the early 1970s. These removed children became known as the Stolen Generations. The Bringing Them Home report 'called for those organizations directly implicated in the forced removals to deliver appropriately worded apologies to Indigenous Australians' and that 'a mechanism be established to allow ordinary Australians to apologize'. In response to this proposal, Australians for Native Title, a voluntary activist group, opened a 'Sorry Book' for public signing on Australia Day 1998. This was the first of many sorry books to be opened for signing throughout Australia. This historical summary is based on Haydie Gooder and Jane M. Jacobs, '“On the Border of the Unsayable”: The Apology in Postcolonizing Australia', interventions, vol. 2, no. 2, 2000, pp. 238-9.

8 The people of the Bundjalung nation are the traditional owners of the land around Lismore.

${ }^{9}$ Gooder and Jacobs, pp. 232, 236 and 235 respectively.

10 Heidegger, Poetry, Language, Thought, p. 54.

11 Kwame Anthony Appiah, In My Father's House: Africa in the Philosophy of Culture, Methuen, London, 1992, p. 240.

12 Michel de Certeau, The Practice of Everyday Life, trans. S. Rendall, University of California Press, Berkeley, 1984, pp. 92-3.

13 J. E. Malpas, Place and Experience: A Philosophical Topography, Cambridge University Press, Cambridge, 1999, pp. 40-1.

${ }_{14}$ Michel de Certeau, Heterologies: Discourse on the Other, trans. B. Massumi, University of Minnesota Press, Minneapolis, 1986, p. 192.

15 Mary Bundock quoted in Eric Rolls, Visions of Australia: Impressions of the Landscape, Lothian Books, South Melbourne, 2002, pp. 215-16.

16 Wait-a-while or lawyer vine is a small sub-tropical palm that grows in the remnants of sub-tropical rainforests around Lismore. It features barbed tendrils that hook into skin and clothing as you pass by, hence the common name.

17 Charles Jarrett, 'The Pioneers', in Tales of the Richmond, unpublished transcript of the author's notebook, Richmond River Historical Society, Lismore, c. 1902, unpaginated.

18 Brett Stubbs, 'The 'Grasses' of the Big Scrub District, North-eastern New South Wales: Their Recent History, Spatial Distribution and Origins', Australian Geographer, vol. 32, no. 3, 2001, p. 296. Harry Frith notes that the term Big Scrub 'might not have been a precise one'. Stubbs agrees. In his research he found that the Big Scrub has 'at various times been applied generally to the entire stretch of country between the Richmond River and the Queensland and New South Wales border', but more commonly 'is understood to apply to that part of the Richmond River catchment situated between the towns of Ballina and Lismore'. This leads to widely varying estimates of the size of the Big Scrub. See Harry Frith, 'The Destruction of the Big Scrub' in Wendy Goldstein (ed.), Rain Forests, National Parks and Wildlife Service, Sydney, 1977, p. 7.

19 The Story of Lismore: 1879-1929: Fifty Golden Milestones: Lismore's Jubilee, Northern Star, Lismore, 1929 , p. 5. 
${ }^{20}$ Louise Tiffany Daley, Men and a River: A History of the Richmond River District 1828-1895, Melbourne University Press, Melbourne, 1966, p. 36.

21 Stubbs, p. 297.

22 Stubbs, p. 304

23 Stubbs, p. 297.

24 Stubbs, p. 311.

25 Stubbs, p. 312; Rodney Harrison, Shared Landscapes: Archaeologies of Attachment and the Pastoral Industry in NSW, UNSW Press, Sydney, 2004, pp. 35-8.

26 For a detailed discussion see, A. R. Buck, The Making of Australian Property Law, Federation Press, Annandale, 2006.

27 Frith, p. 7.

28 Oxford English Dictionary, second edition, Clarendon Press, Oxford, 1989, p. 1079 [B1a].

29 There are some exceptional circumstances where Aborigines are substantive locals, but not in everyday, local use. For a full account see Rob Garbutt, The Locals. A brief outline is found in Rob Garbutt, 'Social Inclusion and Local Practices of Belonging', Cosmopolitan Civil Societies: An

Interdisciplinary Journal, vol. 1, no. 3, 2009,

<http://epress.lib.uts.edu.au/ojs/index.php/mcs/issue/archive>.

30 Renee Redmond, 'The Perfect Backdrop for Local Artist', Northern Star, 11 July 2003, p. 5.

31 'Co-ordinator Named', Northern Star, 18 February 2004, p. 3.

32 Appiah, p. 240.

33 Hubert Dreyfus, Being-in-the-World: A Commentary on Heidegger's Being and Time, Division I, MIT Press, Cambridge, 1991, pp. 189-91.

34 Debates on the New South Wales state government restrictions on land clearing through the Native Vegetation Act illustrate this. In a letter to the editor in the Northern Star one reader links current tree clearing to historical progress, saying, 'It is very easy for people to sit around chatting about the terrible land clearing of the past 150 years. The fact is that if land had not been cleared to produce food, Australia would not have survived as it is today ... We need the freedom to work our land to the best advantage.' The Daily Telegraph reports that farmers are 'fuming' at measures to restrict broad-scale land-clearing they "believe will effectively "lock up" huge swathes of country, devaluing property prices and reducing production'. See, respectively, Rosemary Archibald, 'Freedom to Work Land', Northern Star, 12 November 2003, 'Letters to the Editor', p. 10; Lisa Miller, 'Farmers Fight for the Right to Run their Land', Daily Telegraph, 29 January 2005, p. 17.

35 Dreyfus, Being-in-the-World, p. 163. My thanks to Dr Erika Kerruish for assisting my understanding of Lichtung; any inaccuracies in interpretation are mine.

36 Leela Gandhi, Postcolonial Theory: A Critical Introduction, Allen \& Unwin, Sydney, 1998, p. 54.

37 Heidegger, Poetry, Language, Thought, p. 53.

38 Hubert Dreyfus, 'Being and Power: Heidegger and Foucault', International Journal of Philosophical Studies, vol. 4, no. 1, 1996, p. 2.

39 David Halliburton, Poetic Thinking: An Approach to Heidegger, University of Chicago Press, Chicago, 1981, p. 43.

40 Heidegger, Poetry, Language, Thought, p. 53.

41 Heidegger, Poetry, Language, Thought, p. 54.

42 Dreyfus, Being-in-the-World, p. 165.

${ }^{43}$ Deborah Bird Rose, Reports from a Wild Country: Ethics for Decolonisation, UNSW Press, Sydney, 2004, p. 117.

${ }^{44}$ Kate Grenville, 'Unsettling the Settler: History, Culture, Race, and the Australian Self', in Maria Hooke and Salman Akhtar (eds), The Geography of Meanings: Psychoanalytic Perspectives on Place, Space, Land, and Dispossession, International Psychoanalytic Association, London, 2007, pp. 53, 55. 
45 Rob Garbutt, 'Towards an Ethics of Location', in Anna Haebich and Baden Offord (eds), Landscapes of Exile, Peter Lang, Oxford, 2008, pp. 175-93. Ian McLean, White Aborigines: Identity Politics in Australian Art, Cambridge University Press, Cambridge, 1998.

46 Terry Goldie, Fear and Temptation: The Image of the Indigene in Canadian, Australian, and New Zealand Literatures, McGill-Queen's University Press, Montreal, 1989.

47 Terry Goldie, 'The Man of the Land/The Land of the Man: Patrick White and Scott Symons', SPAN: Journal of the South Pacific Association for Commonwealth Literature and Language Studies, no. 36, 1993, unpaginated, <http://wwwmcc.murdoch.edu.au/ReadingRoom/litserv/SPAN/36/Goldie.html>. 48 Goldie, 'The Man of the Land'.

${ }^{49}$ Goldie, Fear and Temptation, p. 13.

50 David Pearson, 'Theorizing Citizenship in British Settler Societies', Ethnic and Racial Studies, vol. 25, no. 6, 2002, p. 1004.

51 Pal Ahluwalia, 'When Does a Settler Become a Native? Citizenship and Identity in a Settler Society', Pretexts: Literary and Cultural Studies, vol. 10, no. 1, 2001, pp. 65-6.

52 Rob Garbutt, 'White "Autochthony"', ACRAWSA e-Journal, vol. 2, no. 1, 2006,

$<$ http://www.acrawsa.org.au/ejournalVol2no12006.htm>.

53 Geoff Page, 'The Sorry Book: For Lois O’Donoghue', Westerly, Winter, 1999, p. 22.

$54 \mathrm{My}$ thanks to an anonymous referee for this phrase, and the provocations that accompanied it.

55 Martin Heidegger, Being and Time: A Translation of Sein und Zeit, trans. J. Stambaugh, State

University of New York Press, New York, 1996, p. 125 [133].

56 Here I am drawing on Colin Davis's translation of Levinas in Colin Davis, Levinas: An Introduction, Polity Press, Cambridge, 1996, p. 33: 'To the myth of Ulysses returning to Ithaca,' he says, 'we would oppose the story of Abraham leaving his country for ever to go to a still unknown land'. Colin Davis comments that this journey is not a return to the Same but is 'susceptible to an encounter with what it has always suppressed', that is, the Other. 